\title{
Inter-Korean Relations and Multilateral Organizations: Problems and Prospects
}

\author{
YOUNG WHAN KIHL \\ Departmens of Political Sizente, lones State Unizursity
}

\begin{abstract}
The extent of linkage betwetn inter-Korean rekations and North and Sruth Korea's simultaneriss membership in intematinnal organizations (including both inter-s(wermmental onganizations and non-gnemmental organizations) i. examined. This research questions whetber inter-Korean iooperation can b: promuted and altimately be atiained ita multilateral organizatims. Empinical midence shour three types and pattems of linkages: a) swatesfal castes invohing the inter-gntormental nrganizations (IGO) $)$, such as the UNDP. d) unistersfit caser of engaging estublished $U N$ specialized asencies, such ar the UPL and the IIU. and of caser with intermediary reszits, sub as the KEDO and the ICAO. Simuldaneous membership in maltikuteral organizations does not autimatically translate into pmonting inter-Korean riations. Otber ondextud factors, like the international sjstem strituture. changing strategic ensiromment, and the opptirtunity cast estimation by decision-makers, are likely to intervent. The paper discuries political problems

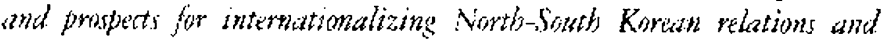
consluter by drawing certain impliations far the mixed results of linkages betteen inter-Korean relations and multilateral arganizations.
\end{abstract}

A revised and updated version of the paper initially presented at the 11 th U.S. Forum on the Problems of the Kore:an Peninsula, leeld at the Cryscal City Marriott Hotel, Constal City, Virginia, Augesst 18-20. 1995 .

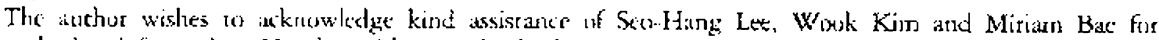
gathering infuemation. He also wishes to chank three anonymons reviewees for their helpful comments. Dires all cotrespendence to Young Whan Kihl, Protessor. Departuent of Political Science, 503 Ross Hall, lowa Scate Uniretsity', Ames, lowa Sedal!, LSA. 
Dromoring North-South Korean relacions via multilateral organizations (like the Urited Varions) and diplomaric forums sounds positive and promising but, in order to be successful, the measure will require careful scrutiny and analysis as to its feisibility. The rescarch question is whether inter-Korean cooperation can be attained through an instrumentality of multilateral organization. If the answer is yes, one has to figure out what the possibilitics and problems might be, given the prevailing conditions of acute tersions prevailing on the Koreas perinsulat in the post. Cold War era.

The literature on the study of intcrnational organizations identifies three types of multilateral organizations: international inter-governmental organizations (IGO), nongovernmental organizations (VGOs), and mulciracional corporations (MNCs). In the presenc study, however, the term "multilateral organizations" is used more in the generic than conventional sense. The Unired Nations is, by definition, a type of 160 that serves a general purpose and an institution of multilateral diplomacy. la the essay, the primary focus will be on the inter-governmental organizations (IGOs) and secondarily on the non-governmental organizations (NGOs).

In the post-Cold War work politics, the rwo Korean states' response and reaction to the changing external environment surrounding the Korean peninsula have been both positive and promotive in adaptation. The Republic of Korea (as ROK hereafter) pursued an active prolicy of $\mathrm{N}$ (ndpolitik and northern policy when interacting with the communise bloc coursuries, which were furmer allies of North Korea. 'T'b. Democratic Pcople's Republic of Korea (as DPRK hereafter), on the other hand, was aggressive in its adaptation to the changing strategic environment, which resulted from the demise of the communist states in Eastern Europe and the former Soviet Linion. The DPRK's negotiation vis-a-vis the U.S. on the nuclear moratorium, for instance, is a classic case of North Kurea acting ats a normal state and rational actor in international diplomacy.

The following questions will guide the present study: what are the possibilities and limits of multilaterial urgatrizations, either the IGOs or $\mathrm{NGO}$, as a way of attaining peace and security on the Korean peninsula? Do they play an enhancing role tomard the reunification of North and South Korea in the distant future? What problems are likely to arisc from pursuing the political and functional approaches to the Korean problem-solving: What are the prospects for the success or failure of relying on multilateral organizations in order 10 assure peace and stability on the Korean peninsula?

To answer some of these guestions the present paper will proced in four steps: (1) identifying trends and patterns of North and South Korean participation in the multilateral organizarions, (2) analyzing the linkages berween inter-Korean relations and multilateral organizations, substuotiated by several case studies of both successful and failed experiments, (3) tindertaking in-depth discussions on (a) the provision in the December 13, 1991 North-South Kored Agreement on "Cooperation in the International Arena," (b) the

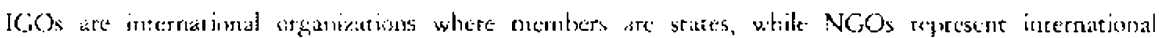
organizations of privare citizens, or simply internitiontally active groujes in difterent stares, jointly working

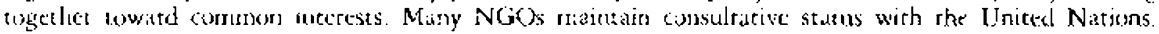
MNCs ine insiness enterprises hoidquatered in one state that invest and optrace extensively in uther tates. The :ern "transmation:i encepprises" (TNEs) is of en conployed to include MNCs and other nomprofit arganizarions, like the plilanionspic foundarions and chusch orgarigarions 
limits and problems of internationalizing intet-Korean telations, and (c) difficulties in attaining Korcalt reunification in the foreseeatble fucure, and ( 1 ) drawing some conclusions.?

\section{NORTH AND SOUTH KOREAN PARTICLPATION IN MULTILATERAL ORGANIZATIONS: TRENDS AND PATTERNS}

Bilateralism and malrilateralism are two varied approahes to diplomacy that often prove to be mutually exclusive and incompatible. Prudence in diplomacy will dictate, according to the rcalist tradicion of intcrnational politics, that the nations give priority to the bilareral forum, in promoting national interests, over the multilateral forum. W'hereas bilatcralism leads, especially on security issues, multilaceralism often follows, especially on nun-security and functional issues as well as other issue areas.

However, in the age of complex interdependence among nations, pragmatism dictates that one must learn to harmonize divergent approaches of bilateralism and multilateralism in inernational diplomacy. The institution of multalateral organizations should not be written off as a diplomatic instrument, for they promote inter-Korean cooperation. The reason is that the institution of multilateral organizations can easily be either exploited or casily utidized by its member scates as a means of providing an useful channel for establishirig dialogut and promoting intcrnational cooperation (Keohane 1998). Multilateralism as a diplotnatic form, in short, should be considered as a valuable instrumental object in Foreign policy (Keohance and Nye 1985). With the preceding caveat, it is useful to investigate irends and parecross of Noth-South Kortarl participation in the muleilateral organizations.

The latest edtion of the Yearlazk. of Imemational Organiaation 1998-99, published by the Linion of International Association in Brussels, indicates that the DPRK is a membet in approximately 330 international organizations (including both ICOs and NGOs) and that the ROK is a member in atxout 19:2 international organizations (including both IGOS and $\mathrm{NGOS}$.

The crend over time scems to be upward in terms of the number of international organizations and agencies with which both the ROK and the DPRK have joined as memiers. Of the total of 1972 international organizations, with which the ROK is affiliated in $3998-99$, eighty-one headquarters or secretariats of these organizations are located in South Korea. The comparable figure for North Korea is 330 international organizations, with mernbership, and wo incernational organizations, with secretariat located in Pyongyatig, which, in these cases, are the LNDP offece and the Science and Technology

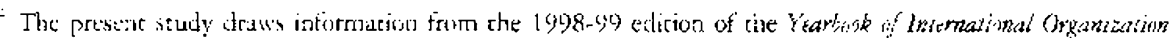

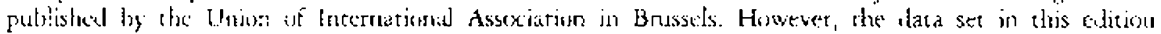

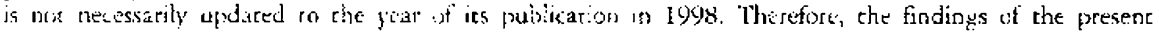

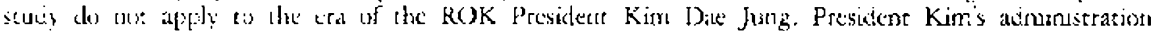

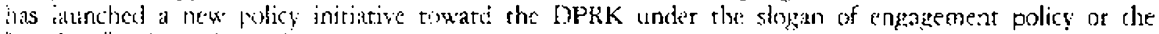

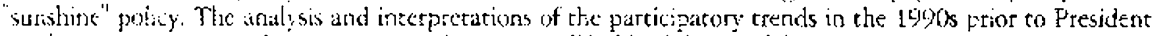

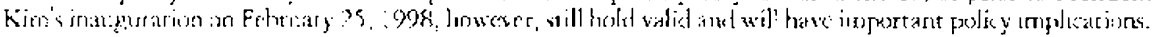

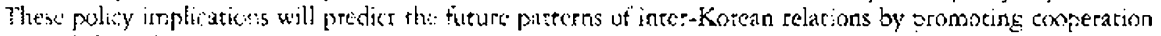

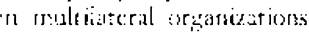


TAHI. 1. MEMbership OF NORTH AND SOETH KOREA IN INTERNATIONAI ORGAANTZATTONS

\begin{tabular}{ccc}
\hline & \# of Headquarters & \# of Total International Organizations \\
\hline R6K & 81 & 1972 \\
DPRK & 2 & 330 \\
\hline
\end{tabular}

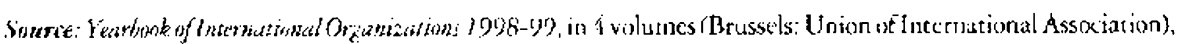
Volume ? (Geogtaphic Voiune), pp. 883-898.

Advisory Commitec for Southeasr Asia (of the National Commission for Oceanography). ${ }^{3}$

Theorerically, there are three sets of multilateral organizations that require differentiation and analysis in the present study. These are: (l) the ICOS for which only North Korea is listed as a member, (2) the ICOS for which only South Korea is listed as a member, and (3) the IGOs for which both North and South Korea are lisecd as members. Of a tutal of several hundred IGOs which fall under the "conventional" type (i.e., categories from $A$ through D) as listed in the Yeatbone of Intomatimal Onganizations, published by the Union of Incernational Associations in Brussels, South Korean membership in some fifty-tive IGOs cunstitutes only about ten percent of the total populacion of IGOs, whilc North Korean membership in thirty-seven IGOs constitutes seven or eight percent of the total IGOs. Most of these international organizations in which both North and South Korea are listed as member states are, generally speaking, either insignificant or trivial as to bypass artention by the orditrary students of international organization.

According to an official account of the ROK National [inification Ministry, as of the end of November 1994, the DPRK retained membership in some twenty-ehree multilateral organizations, including thirceen UN agcncies and ten KGOs, while maintaining diplomatic ties with a total of 133 countries. The ROK, in contrast, retained membership in fifty-five multilateral organizations, with eighteen LX agencies and thircy-seven $16 \mathrm{OO}$, while maintaining diplomatic ties with a total of 174 countrics. ${ }^{i} \mathrm{~A} 1992$ study by the ROK Ministry of Foreign Affairs Institute of Diplomacy and Narional Sccurity also published a list of sixteen UN Specialized Agencies and thirty-six other IGOs in which the ROK was a member, and a toral of seventeen IGOs including twelve UN agencies in which both the ROK and the DPRK wcre listed as members." These figures of 1992-93 appear to be conservative, and underestimated as noted below.

for the purpose of the present study the third category and type of IGOs as listed

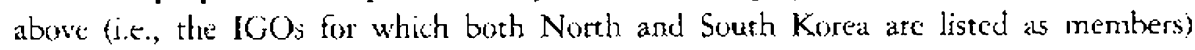

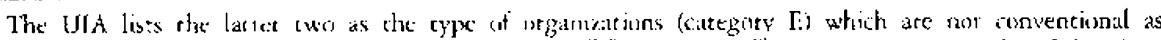
they "ctmanare from isther places, persuns, or bodies." "Conventional" organizations are either federations of theernational or ganizations (calegory' A), universal membershup organizations (ratcgory B), intcrconcinenra

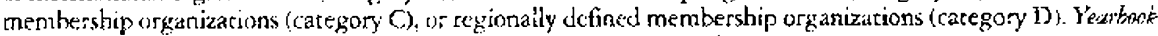

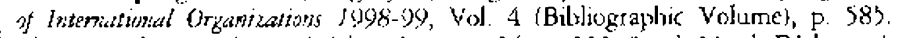

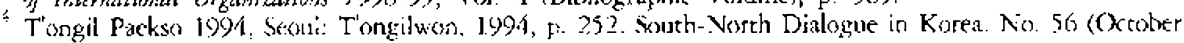
1992). Seoul: Office of the Siouth-North Diatrgue. 1992, \&. 33 .

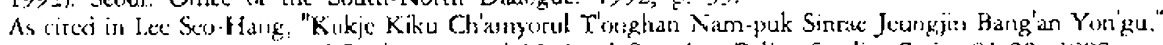
Forscign Minisery Insrirure of Diphmiky ind National Security. Policy Studies Series 91-20, 1992, pp. $15 \cdot ! 8$.
} 
will be singled out for in-depth analysis and discussion. In ordet to simplify the task of analysis, the present study will. rely exclusively on the official list of IGOs that the ROK government sources have provided. 'Table 2 shows a list of twenty-three IGOs for which troth the ROK and the DPRK are listed as members.

\section{TABLE 2. INTER-GOVERNMENTAL OHGANIZATIONS WITH SIMLLTANEOLS MEMBERSHIF OF BOTH NORTH ANL SOUTH KOREA}

\begin{tabular}{|c|c|c|}
\hline No. Inter-Govemmental Organizations & $\begin{array}{l}\text { Year } \\
\text { ROK }\end{array}$ & $\begin{array}{l}\text { Entry } \\
\text { DPRK }\end{array}$ \\
\hline 1. "Jhe UN (eisited Yations) & 1991 & 1991 \\
\hline 2. WHO (World Health Organization) & 1949 & {$[4] \div 3$} \\
\hline 3. 'LNCTAD (United Narions Conference on Trade and Develupment) & 1965 & 1973 \\
\hline 4. AALCC (Asla-Africa Ligal Consultarive Committe) & 1974 & 1974 \\
\hline 5. IOI.R (International Oryanization of legal Reform) & 1978 & 1974 \\
\hline 6. 'UPU (C'niversal Postal Union) & 1949 & 1974 \\
\hline 7. WIPO (Worlit Intellectual Property Organization) & 1979 & 1974 \\
\hline 8. LAEA (International Atomic Energy Agency) & 1957 & $19: 4$ \\
\hline 9. "LNESCO (Ulaited Narions Fducatmal, Scienrific, and Culturad Organization) & 3950 & 1974 \\
\hline 10. WMO (World Meteorological Organization) & 1956 & $19: 4$ \\
\hline 11. ITU (Iatcermational Tdecommumications Union) & 1952 & $19: 4$ \\
\hline 12. ICAO Internatiuna! Civil Aviation Organizations & 1952 & 1977 \\
\hline 13. $\mathrm{FAO}$ (Foxd and Agricultural Organizatsin) & 1949 & 1977 \\
\hline 14. IOC (International Oceanography Committee) & 1961 & $19 \div 9$ \\
\hline 15. UNIDO (L.N. Industrial Developmene Organization) & 1967 & 1980 \\
\hline is. CODFX (Alinemarious Cammissioni & 1970 & 1981 \\
\hline [7. [BWM (Internarimat Bureaulu of Weigh \& Measurement) & 1059 & 1981 \\
\hline 18. IMO (Intermational Marisinje Organization) & 1961 & 1986 \\
\hline 19. 'IHAD (International food \& Agticultafil Development) & 1978 & 1986 \\
\hline 20. ICCPPR international Center inc Cultural Propetty Preservation and Restoration) & 1968 & 1986 \\
\hline 21. JHO (Interlational Hydrogeaphic Organication) & 1972 & 1987 \\
\hline 22. WTO iWorld Tourism Organization) & 1974 & 1987 \\
\hline 25. IfHe (nternatiunal Buxeau of toducation) & 1962 & 1975 \\
\hline
\end{tabular}

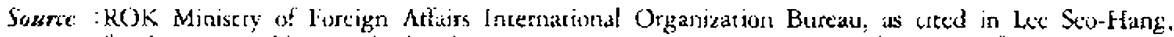
"Kukje Kigu Chamyortul 'T'onghan Nampukhars Sinue Jeungijn Pang'an Yongu," ROK Minisery uf Forcizn Altairs Inscituce of Diflomacy atod Security Policy Research Series 91-20 (1992), pp. $15-18$ and upriated io $190 \%$

Of the total of twenty-rhree IGOs listed above, thirtcen (with asterisks) are the United Nations Sperialized Agencies or the UN-affiliated/sponsored organizations, while the remaining ten are IGOs not affiliated with or sponsored by the United Nations. All of these IGOs except the AALCC are universal organizations with open membership. 'The remaining categories and types of $J G O$ s tend to be regional or functionally-specific $1 \mathrm{GOs}$, in which only either the ROK or the DPRK has single membership.

Ibid. Alsn, see Young, Whan Kihl, "Kukge Kikawa Nambukhan Kyomu Hyupryok: Munjejomkwa Jonmang." Chokkunu Nampuk Kwankycwi T'ongil Hankukui Mosaek. Stoul: Korea University Asiatic Rescatch Center, 1093, nip. 243.46 . 
The list of IGOs in Table 2 secms to be conservative and underestimated by virtue of its exclusion of such important international organizations that belong to the borderline cases berween governmental and non-governmental activities. The contusion arises from the fact that the DPRK is a communist state and, as such, is less likely than the ROK to promote private and non-governmental representation and iffiliation with international bodies. The cases in point, with the official listing in Table 2, are: a loost of international orgatizations like the JPU (Inter-Parliamentary Lioion), IRC (International Red Cross), and the IOC (Intenational Olympic (ommitec) with its official designation being the NGO. Substantive activities are clearly more JGO+oriented and quasj-governmental.

\section{THE LINKAGE BETWEEN INTER-KOREAN RELATIONS AND MULTILATERAL ORGANIZATIONS: AN ANALYTICAL APPROACH}

Ote possible role that the IGOS can play is to make itsell available as a diplomatic forum for the member countries in an atcenpt to bring about dispute settlements. The literature on the third party intervention's intermediary role in conflict resolution is excensive. Depending on the nature and extent of third party intervention, the multilateral organizations can render the parties in conflict valuable service with minimal or maximal spillover effects. Their role can be une of either facilitation ur dispute setrlement, by virtue of providing good offices, mediation, and adjudication.

The sesearch question of the presene study is to dscertain whethey and bow promocing inter-Korean cooperation can be attained via the instrumentality of multilateral organizartions. The researd design of these questions will suggest that the dependent varible is inter-Korean cooperation $(A)$, while its indepentent variable is multilateral organizations (B). What, then, is the nature of linkagres between these iwo sets of variables and the patterns of their relationship?

The promotion of inter-Korean cooperation via muleilateral institutions is adrnirable in intent but ditficult to carry out in practice. 'The rewson is that the dependent variable (promoting inter-Korean cooperation) is essestrially a bitateral form of interaction and a rype of cooperarive endeavor between two sovereign actors. The independent variable (the instrumentality of multilateral organizarions) is a third party intervention for facilitarion or dispute settlement, which is open to the two Korean states for their services and decision-making. The dependent variable $(A)$ is not contingent upon the independent variable (B) in the real world, beciuse a host of other factors (such as the intervening vartatles (C) exist betwecen (A) atul (B). These include, arnong others, the aature of the international system structure, the strategic environment in world policics, and considerations of opportunity costs and their astimation by the decision-makers.

For a set of preferred outcomes to come into being (i.e., the promotion of inter-Korean

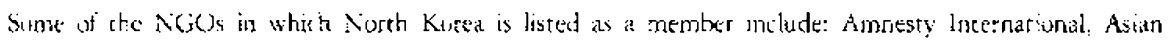

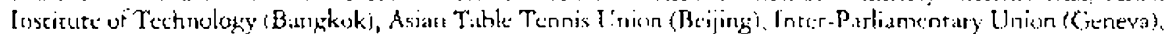
and Internationat Asscciation of Lighehousc Autlorities (France) among ot hers. For the listing of some

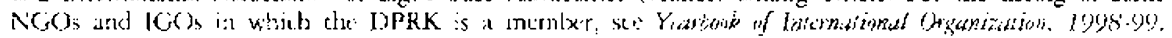


cooperation $(\hat{A})$ ), the independen variable of multilateral organizations (B) must be linked with orher explamatory variables (C) (i.c., the pose-Cold War security enviromment of moderating inter-state contlicts; lessening of tensions). After all, the independent variable of multilateral inscitutions is contingent upon the structure of the international system.

Empirical evidence on the Korean peninsulat show's that the world has witnessed the following threc types of linkages berween the multilateral organizations and the inter-Korean cooperation: a) successful cases involving the IGOs, like the UNDP, b) unsuccessful cases of engaging LN specialized agencies, such as the $\mathrm{l}$ PU and the ITU, and c) cases with mixed results, defined to bc somewhere in-between the successful and unsuccessful experiments, like the KEDO. The teasons for success and failure of these linkage experiments will be discussed in detail in the next section.

As a gencral consideration, the DPRK has larely come to rely more on the service of certain humanitariat ICOs, like the UN World Ford Program (WFP), and other NGOs. Food assistance will alleviace dire economic difficulties in the country. This change in orientarion of the North Korean authority has lad positive spillover effects not only with other multilateral organizarions, but also in facilitating inter-Korean cooperative endeavors to render humanitariass assistance to the North.

The famine and economic distress also forced North Korea into greater openness toward some multilateral organizations and, as a consequence, more information about the North Kurean teconomy has become readily available. The United Nations Development Program (INDP), in fact, has been working with the North Korean government to construst standard national accourts, and some of the data werc released to the International Monetary Fund (IMF) in 1497.3 Other international bodies, such as the FAO and the INW'FP, have ieleased data associated with their faminc rclief work.

\section{Case Studies of Successful and Failed Linkages}

Sorne case studies on ICiOs, UN Specialized Agencies, may be cited to see whether and how the task of promoting inter-Kortan cooperarion is dise international arcna has been carried out. Greater promise and possibility exist in the areas of such functional and technical ICSOs as the International Civil Aviation Organization (ICAO), International Maritime Organization (MO), World Metcorological Organization (WMO), UN Food and Agricultural Organization ( $\mathrm{HAO}$ ), and the World Health Organization (WHO)." Because of the rechnical and relatively non-controversial nature of the subject matter, there is a greatcr possibility that the North and South Korsan participation in thesc functional and technical IGOs may offer opportunities for greater cooperation and understanding between the former astuersaries.

For instance, the exchange of information includes air navigation safety, waterway

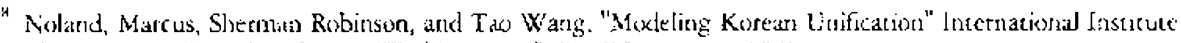

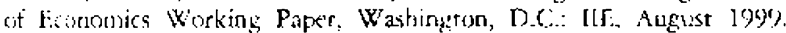

"Funcrionalism seeks to build "pease by pieces" through exparkting cransnational and muleulaetat organizations.

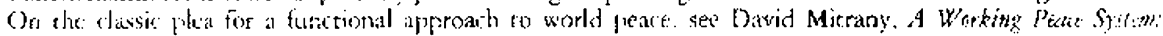

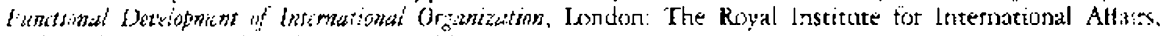

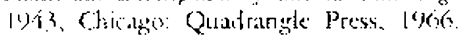


traffics (along the coast and in the high scas adjacint to the cerricorial waters), weather forceasts and reporting, the monitoristg of crops during the growing scason, and the reporting on the outbreak ant spread of epidemics. Some areas on which IGOs focus deal with potential inter-Korean "coopcration in the international arena."

The establishment of air corridots over the DMZ. (Demilitarized Zone), likewise, can be rorked our between North and South Korea under the guidance and direction of dhe ICAO. This will facilitate the international airline navigation and overflight beween the major cities in Northeast Asia, such as the flight to and from Iokyo and Beijing. North and South Kures certainly can get togethet and utilize the multilateral organization framework of the $I \mathrm{CAO}$, in order to come up with a rational plan of air navigation and safty ower the Korean peninsula airspace. ${ }^{10}$ Whecher such a cooperative measure can be worked out, however, is not so much of functional and cechnical ratsen dorre as it is the presence of prior polirical and administrative decision-making at the respective government level in North and South Kored. A similar theory applies to other functional and exchrical areas of inter-Korean cooperation via multilateral organizations.

Examples of failed experiments and wasted opporrunitics are the unsuccessful postal cxhanges and telecommunication linkages between North and South Korea. Clearly, the instrumentality of the Liviversal Postal Linion (UPL) and the International Telecommunication Union (ITC) exists for North and South Korea which are both member countrits of these IGOs. Yet, there has nox beern any mail or telephone call exchanges actoss the DMZ, other than tor political and propaganda purposes. The reason for these failures is nut difficult to fathom. It is not so much the availability of technical means as it is the political will and determination.

The nore ambitions and challenging arcas of possible inter-Korean cooperation via multilateral oryanizations are in functional and economic 1GOs, such as che United Vations Development Program (L,NDP) and the United Nations Jadustrial Development Organization (UNII)O). Actually, North Korta has actively solicited and utilized the instrumentality of the UNOP in order to cary out its own infrastructure-buiddisig and modernizacion of hey indusiries, such as power plants and transportation.

The ane of the Rajin-Sonbong area development project thar North Korea has adopred as its development policy was initially launched with the support and survellance of the LNDP team. The Linited Nations Development Program (UNDP) was also instrumental in arranging a series of international conferences of experts and interested partics in vatious locations of Norrlkast Asia, including Ulan Bator and Seoul. Both North and Soutly Korean delegates parcicipated in these conferences along with representatives from Japan, China, Russia, and the U.S. Pyongyang sent representarives to the UNDP sponsored conference. "Themaric Roundtable Mecting on Agricultural. Recovery and Environmencal Protection in the DPRK," which was held in Geneva on May 28-29, 1998. It was attended by officials from twenty-five nations and $\mathrm{I} F \mathrm{FO}$, including the EU, the LiN: agencies, the IMli, and the World Bank, as well as the various NGOs donating humanitarian foud assistance to North Korca.

The lCAO was inserumentaj in establishing air cortidus wer Noth Korea that wili shorten the airlitu

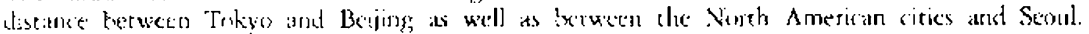


In addition, the KEDO experiment seems to have broken new ground in pronoting inter-Korean cooperation via the instrumencality of multilateral organizations. The KEDO was established in New York on March 9, 1995 as a nultilateral institution o deal with the North Korean nuclear problem. It was launched by twenty nations, with the governmencs of Japan, the Republic of Korea, and the Lnited States acting as its founding members. North Korea's rise as a nuclear weapon state will pose as a serious security threat to the regiond actors in Northeast Asia. North Korea was giver an alternative incentive, under the KEDO arrangerment, to pursue peaceful uses of nuclear energy instead of acquiring the nuclear weapon state status.

The KEDO's three-fold objectives, as stipulated in Article II of its Chatter, are to: (I) provide financing and delivery of a Light Water Reactor (LWR) Project to the DPRK, (2) provide the DPRK with interim energy supplies in the form of heavy fuel oil for heating and elcetricity production (until the firse of the light water reactors is completcd), and (3) provide for the implementation of any other measures deemed necessary to accomplish the objectives of the Agreed Framework. In ofder to achieve this set of purposes, the KEDO has done a number of works since its founding in 1995.

The KEDO's initial task, to finance the shipment and delivery of heavy oils to North Korea, has been carried out on a regular basis despitc some difficulties of raising the needed funds. However, with the launching of the LWR construction project in 1997. the Kl:DO workload and activities have steadily incteased. Ihe signing of the Supply Agrecment with the DPRK, on December 15, 1995, was followed by the additionat sigrning of eighteen doxuments and six related protocols regarding the implementation of the agrement on the 1.WR supply to North Korea. ${ }^{1:}$ Flirthermore, since the groundbreaking ceremony, hetd on August 19, 1997, at the project site, the KEDO has established a liason office in Kumho, South Hamgyong Province. As the workload increases, the KEDO's task performance and expansion are most likely co continue in the days aheiat. I:

Whether these KEDO's activities, which have been accomplished so far and to be undestaken in the days ahead, will result in a nuclear-free North Korea still remains to be seen. In the absence of official ties at the government level, the KEDO serves as a useful channel of communication between the two Koreas. However, whether the $\mathrm{KEDO}$, as an implementation agency of the (ieneva Agreed Framework of October 1994. can achicve the ultimate outcome of establishing a nuclear weapons-free Korean peninsula (as part of the larger question of nudear nomproliferation in Kast Asia), remains to be seetr as well. This will most likcly cause a sensitive political and strategic issuc over which the KEDO has limied control.

All in all, the conclusion is that (1) there exists empirical evidence of mixed results in so far as the linkages between inter-Korean cooperation and multilateral organizations are concerned, and that (2) a successful outcome is hard to come by in the area of

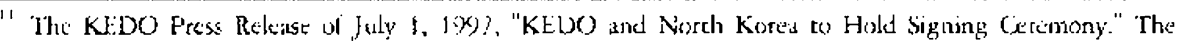
list of protexisk included a totai of nine procedures, eighe memorandum of understandings, and rwo recorts.

12 Young What Kilhl, "lutwetions of the KEDO." In BaeHo Hahn and Chae-Jin Lete eds. Pankens of Inter-Korean Relution (Scisul. The Sejomg Instivete. 1999), prs. 115-36.
} 
institution building via multilateral diplomacy. In order to explain further why the impact of mulcilateral organizations is so limited in promoting inter-Korcan cooperation, we will nced some discussions on the erue nature of on-going inter-Korean relations with a view to finding the underlying causes and factors of maintaining peace and security in the region of Vortheast Asia.

\section{DISCUSSION}

The preceding cases provide clear examples of what the IGOs can do to tailor to the needs and wishes of the member councry, and retfect the priority of the political elites in their starch for national and regional development projects. As long as there is politikal will and determination of the host government involved, the instrumentality of such IGOs as the LNDP can work out orher difficulties. Hopefully, other IGO experiments similar to the UNDP involvement in the Rajin-Sonbong area with development can be enticed and concouraged in the days ahead to engage North Korca in the process of deeprang the international necwork of conperation in economic development on a regional basts :

\section{The Inter-Kortan Agreement on Cooperation in the International Arenat}

As far as the mutual interaction between the two Korean states is concerned. North and South Korea negotiated and signed the historical "Agrecment on Reconciliation, Nonaggression, Exchanges, and Cooperation Between the South and the North" (to be referred hereafter as the basic agreement), on Decemher 13, 1991. "The basic agreement reaffirmed the "ptinciplts for unification of the fatherland" by proclaiming, in the preamble, that they were "determined to remove the state of political and military confrontation and achieve narional reconciliation...to aroid armed aggression and hostilities, rectuce ceision, cosure the peace... realize mulcifacced exchanges and cooperation (so as) to advance common national interests athd prosperity. "I.t

One noteworthy feature of the basic agreement is the reference to inter-Kocean conperation in the international arena, the provision that requires detailed exposition and analysis, as will be slioxin below. Ample evidence exists that the framers of the basic agreenent struggled with the chiestion of how to best definc the nature and character of their nutual relacions. "The basic agreement in its preamble states, for instance, that "recognizing that their relations, not being a relationship between states, constitute a special interim relationship stemming from the ptocess towards unification."

The relcrant question in this regard is: "What is the basic nacure of inter-Korean relations?" Is it a special cast of international relations, or should it be treated as a

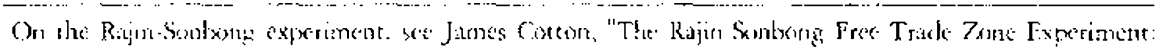

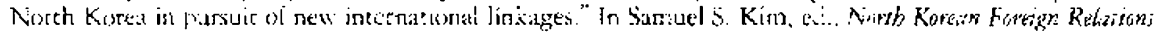

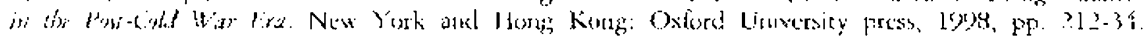

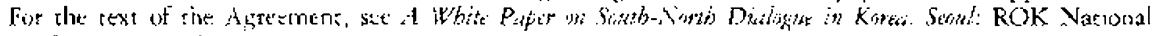
linisidatur Bostel, lys;. 
"normal" or "abnotmal" business of inter-state diplomacy?" The two Korean staces have alternated their behaviot toward one another, not surprisingly, by relying on the seemingly two conflicting definitions depending on the specific context and circumstances. The 1991 basic agreement has clearly detined inter-Korean relations as a kind of special (not normal) relationship. The fact that North Korea had to join the Linited Nations as a separate entity in 1991 , chespite its expression of reservation not to do so, is a confirmation "by deced," if not in rheroric, of the fact that the two Koreas do coexise and that they must act as "normal" states in conduccing business with the world organization.

Despite this espoused agreement on principle, the practical needs and exigencies dictated the two Korean states to behave toward each other as if they were nomal sovereign states. ${ }^{3}$ However, the leaders of the two Korean stares, in [99) 1-92, translated the respective concern and appretension into the pusicive forum and framcwork for moving coward improved inter-Korean relations. The sigring of the basic agreement, on December 13, 1991, was clearly a manifestation of the resolve by the two Korean regimes to internalize the newly emerging post. Cold War security order into the inter-Korean detente and rapprobemest.

Since 1992, however, inter-Korean relations have gone through cooperation in theory but conflict in practice. Norch Korea's "suspected" nuclear weapon's program was the alprit that blocked the snooth transition of dic Korcan peninsula into the post-Cold Wat peace system. The unfolding of the nuckeat controversy in 1993-94 thus quickly negated the promise of Korean peace in the post Cold War.

Now that the October 1994 Geneva Agreed Framework berween the IIS. and the DPRK is signed, to frecze North Korea's on-going nuclear program and dismantie it eventually, the possibility of reviving the momenturn for inter-Korean peace and de-nuclearization has also improved. 16 This is why we need to re-examine the terms of the basic agrecentent in regards to the coopcration in the international arena to see whether and under what conditions such an attempt raky bear incended fruit.

North and South Korea agreed, in the preamble of the basic agreement, that "their relations, not being a relationship between states, constitute a special interim relationship stcmming from the process towards unification" and, therefore, they "pledge to exert joint efforts to achieve peaceful unification." To achieve this objective, the two sides agreed on joint efforts to promote cooperation in the international arena.

The two sides went on $t)$ expess their desite, according to bhe preamble of the agretment, to "reduce revision and consure the peace" and to "reatize multifaceded exchanges and cooperation to advance common national interests and prosperity." To realize this aim, two specific provisions were inserted into the basic agreenent as Article 6 and Article 21. An ambitious, yer pietistic statenont of principle was proclaimed in Article 6, which provicles that "che cwo sides shall cease to conpete with or confront each other in the international arena and shall cooperate and endeavor together to promote national prestige:

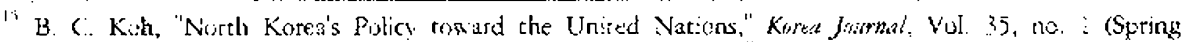

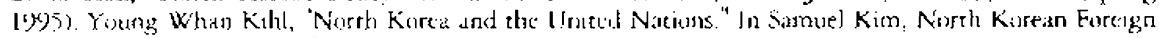
Relarions. Op. Cit. pp. 299-?9.

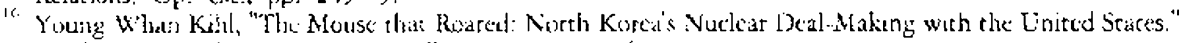
Patilik fritis: Vol. XIIT, No, ? (Fail 1998). pp. 5-?6 
and interests." $A$ firm, yet matter-of-fact statement on the norms of action was also inserted in Arcicle 21, which provides that "che two sides shall cooperate in the incernational arena in the economic, cultural, and various otber fields and carry out joint undertakings abroad."

To realize these overall objectives of promoting inter-Korean cooperation in the international arena, the two sides also signed the protocols on the compliance with and implementation of each provision of the basic agreement cluring the eighth Nurth-South high-level meeting in Pyongyang on September 17, 1992. They were successful in adopting separate protecols on three of the four componenes of the agreement: (a) rcconciliation, (b) nonaggression, (c) exchanges and cooperation, leaving the protocol on and (d) military and security matters yet to be negotiated and rorked out.

The protocol on the Article 6 provision of the basic agreement contains four additional statements in regards to the measures of promoting inter-Korean cooperation in the international arena, as follows:

Onc: "The South and the North shall not vilify and slander each other in the international arena, including at intemational meerings, and shall closely cooperate with each other in arder to maintain the dignity of the Korean people." (Article 21)

'Two: "lhe Souch and the North shall consult with each other on matters affecting national intcresss and take the neccssary joint masures." (Article 22)

Thret: "The Sourh and the North, in order to promore the common interests of the Korcan people, shall maintain close contacts between their diplomatic missions overseas in areas where both sides have diplomatic missions." (Arricle 23)

Four: "l'he South and thc North shall channpion and protect the exhnic rights of overseas Koreans and shall endeavor to promote reconciliation and unity among them." (Article 24)

The Protocol on the Compliance with and Implementation of the Provisions of Chapter III (South-North Exchanges and Cooperation), of the basic agreement, has the following main provision and two sub-provisions: "The South and the North shall cooperate with each other in various sectors of the international economy and shall promote their joint presence abruad" (Article 5). This is followed by two sub-provisions: (1) "The South and the Norch shall cooperate w the eachother in various international events and international organizarions in the economic ficld" (Article 5.1), (2) "The Sorth and the North shall discuss and carry our measures to promote their joint presence abroad in the economic fietd" (Article 5.2).

Lintortunately, it turns out chat neither the South-North yoint Reconciliation Commission nor the Joine Exchange and Coxperation Commission, an implementation mecharnism cstablished to carry out the Ptotocol on the Compliance with and Implementation of Chapter 1 and Ill of the North-South Agromont, was successfully implemented due to the political contingency ank controversy over. North Korea's "suspected" nuclear weapons 
program. At least on paper, then, the two sictes have come to full agreement on the specific measures of how to implement the terms of the North-South Agreement on all aspecss of the relacionship except the ones on the military.

The preceding discussion and textual abalysis of the terms of agreement clearly suggest that in the absence of political will, the formal inter-Kurean agrecment amounts to nothing more than a piece of paper and that the implententation plans, however perfect and parsinonions they may look, are nothing more than at wasted effort and an exercise in furility.

\section{Inttriationalizing Inter-Korean Relations: limits and Problems}

The need for ctoperation in the international arena, in light of the growing trend of borh Kurcas to participate in multilateral orgarsizations is greater today in the post-Cold War cra than it was anytime in the past. Whether such a possibility of "cooperative" interaction can take place, however, is neither obvious nor to be taken for granted. To make the possibility come true, the ptior agreement and consensus between the two regimes must be present, as well as the political will and determination to succeed.

It is clear that the proposal for cooperation in the international arena was policically mutivated and influcneed with which to begin. As early as 1973, the Secul government took an official stance at promoting inter-Korcan cooperation, when the "Special Foreign Policy Statement Regarding Peace and Inification" on June 23, 1973 sfated that South Korea "shall not oppose North Korea's participation with us in international organizations, if it is conducive to the easing of tension and the furtherance of international cooperation." 1.7 A similar policy stance was presented by the Seoul government in 1989, when the "Special Presidential Dedaration for National Self-Estcem, Unification, and Prosperity" on July $7^{\text {th }}$ (rlke pronuuncemene on Vorthern Policy) stated that Sourh Korea hopes "to bring to an end wasteful diplomacy characterized by compctition and controntation berween the Souch and North, and to cooperate in ensuring rhat North Korea makes a positive contribution to the international conmunity" and that "representatives of South and North Korea will contace each other freely in international forums and will coopcrate to pursue the comvun incerest of the whole Korean nation." 18

The Pyongyang growernment likewise followed the Seoul government lead in launching international campraigns for strengthening its ties with the Third World Non-Aligned Nations Movement. In May 1973. North Korea scored a major diplomatic rictory by joiring the World Health Organization (WHO), acxuiring an observer status with the United Nitions. North Korca campaigned for the United Nations Ceneral Assembly to atlope the pro-Pyongyang resolution endorsing its position on the Korean question. ${ }^{14}$ Kim Il Sung said in his new year address in 199t, that his government and party

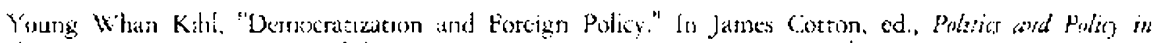

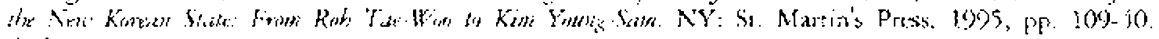
libid.

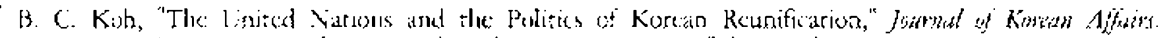

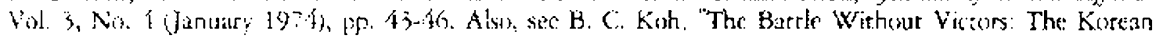

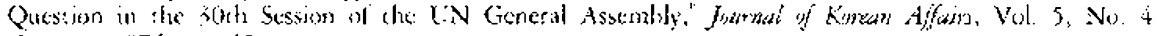
(fandary :976), F. 45 . 
"shall comsistently adhere to the foreign policy of indegendence, pace. and friendship to mect the recutements of the present situation" and also "shall work hard to abohish the old international, political, and economic orders of domination and subordination, establish new ones on the basis of equality, juscice, and impartiality and development of North-South cooperation on the principle of collective self-reliance."20

Enhancing inter-Korean cooperation via multilateral organizations, as a result of having irmplemented cooperation in the international areua, sounks grod in theory but it is unlikely to matetalize under the prevailing conditions in the 1990. "31 An acute tension and mistrust continue to persist on the Korcan peninsula due to an acrimonious and hostile atritude of North Korea toward South Korea folloxing the death of Kim 11 Sung in 1944.

Buth the pro atnd the con views on the nution of inter-Korean cooperation in che international itena may be given. As for the pros view, it is reuc that the possibility is grearer, now that the post-Cold War era and the post-Kim 11 Sung cra have dan'ned. The new era means that no tonger will ideology reign but pragmatism in diplomacy, as wall as in the economy where national interest considerations, rather than the political dogma and ideology, will dictate foreign policymaking and implementation in the respective Korcan sares of North and South Korea. At least, one can hope that this pragmatism will reign and prevail in inter-Kurean relations.

The new post-Kin Il Sung era also means that North Korea under the Kin Jong If regime will move toward the direction of a greater open door and a more pragmatic foreign econornic policy that promotes joint ventures and special economic zones. North Korea, in fact, achoped a new policy line of "agriculture first, lighe industry first, and forcign trade first." This is a manifestation of the pragmatic thinking and action of the: North Korcan elite. "I

The Scoul government, under the newly adopted Sunshine policy toward North Korea, also continued to move along the path of greater interaction with the North by separating politics from economics in its tradc relations with the North. ${ }^{23}$ Hence, the possibility is wide open tor both North and South Korea to interact positively in the international aremia, vid any one of atce incernational agencies and multilateral organizations in which both Koreis choose to participate. The Secul govermment has consistently pursued the Open Dowe policy and interaction with the outside world. The economic miracle of the Han River, in fact, was erected on the rock hed of an export-led straregy of ind ustriatization of the economy. The economic miracle of the Taedong River may also be in the offing, depending on whether or not North Korea pursucs the new Upen Door policy and

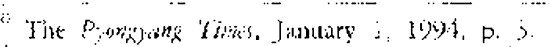

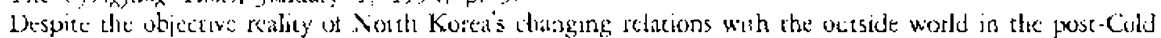

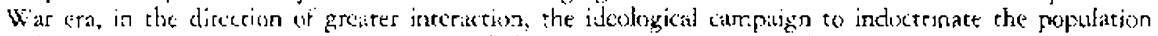

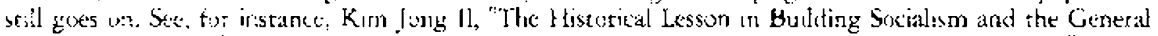

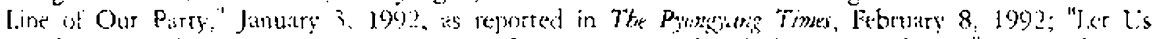

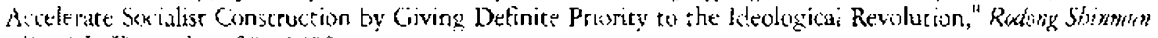

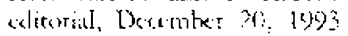

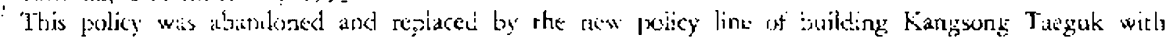

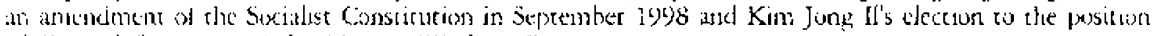
a: Cicheral Sererary all the Korean Workers Parcy.

As tor Seoul's new policy intjanive twward the Nurrh. see Young Whan Kihl. "Seoul's Engigement Policy

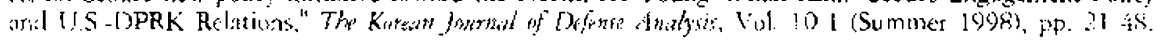


expott promotion like the ones Deng Xianping's China has accomplished sine 1978.

As for the con view, one should not underestimate the difficulty in promoting inter-Korean ccoperation in the international arena. Formidable obstructive barriers exist and continue to persist for reasons of national pride of "Juche" in North Korea and economic downturn due ti) a financial crisis and an IMF-managed economy in South Korea. Deep-seated distrust and animosity also prevail between North and South Korea that stem from the unfortunare past of the internecine Korcan War. The claims of legitimacy and sovereignty also provide the shield with which to hide their raw political ambition and arrogance that the respective Kurean ruling elite harbors roward the opponent regime.

Thus, it is not a question of "theoretical possibility" and "practical necessity" that will keep the two Kortas from actively pursuing cooperation in the international arena. Rather, it is the absence of the political will and determination by leadership to carry out the terans of agrement already put on paper in the form of historical "ayreement on reconciliation, nonaggression, exchanges, and cooperation between the South and the North." Unless and until the psychological and attitudinal barriers are removed by restoration of mutual respect, confidence, and trust, no genuine cooperation and peace-building via multilateral organizations will hold and thrive on the Korean peninsula.

'the record of inter-Korcan rivalry and conflict revals that there is a strong zero-sum gatne assumption that reigns rather that the brotherly and harmonious relations that are based on fraternal love and compassion. Inter-Korean relations bave been acute, cutthroat, and antagonistic with sworn enemies. Linder these circumstances; what can be desired realistically is to do damage control and minimum cooperation rather than to go all the way out for miracles and maximum cooperation. The time is not ript or right for the two Korean states to aspire to maximize cooperation in the intcrnational arcena in the pust-Cold War cnvironment. North and South Korea, in shorr, still suffer from the trausma of the war of years past and the lingering effects of Cold War rivalry between the two archenemies.

Finally, internationalization of inter-Korean relations, via multilateral organizations, is "theoretically tlawed and conceptually incomplete." Whereas inter-Korean cooperation is bilateral in furmat and recpuires direct, face-tu-face contact and interaction, multilateral organizarions, like the Inited Narions forum by definition are plurilareral in retationship and muliple in membership. Since intcr-Kotean relations are basically forms of interaction herween swo sovereign entiries called the ROK (South Korea) and the DPRK (North Korea), enticing them out of the way to promote cooperation in the international arena in the multilateral setting of IGOS is neither natural nor to be taken seriously. History shows that the ROK and the DPRK diplomats at the U.N., since they established an ulaserver stalus with the United Narions in 1973, have not carried out the substantive or meaningful dialogue. This failure of meaningful interaction between the diplomats of the two sides is also the case since the two Koreas were admitted into the Linited Viarions ats regulax members on September 17, 1991.27 


\section{Achieving Korean Reunification in the Past-Cold War Fra?}

Since the Korean people suffered from the tragedy of territorial partition after World W/ar II in 1945, they have aspired and struggled to bring about the reunification of their country by their own efforts. In response to this popular and nacionalistic demand, the two Korean regimes have worked out basic principles on the reunification of Korea. The South-North Joint Communicuese of July 4, 1972, for instance, ardopted the basic: "principles for unification of the fatherland."

In the Joint Communiqué, North and South Korea noc only agreed that national unification of the Korean people was "a just cause," but also their reunification should be achieved through an independent, peaceful, and national means. This shreefold principle of national unification, as set forth in the North-South Joint Communique of July 4 , 1972 , stipulates that unification should be achieved through (1) independent Korean efforts "without being subject to external imposition or incerference," (2) peaceful means, that is, "not through the use of force against cach other," and seeking (3) a grearer national unity, "transcending differences in ideas, ideologies, and systems."2s

Peace and rappontiment (as shown in the December 1991 "basic agreement") epitomize the Korean people's determination to internalize the value premise of the new post-Cold War era. Despire the tanguage and rhetoric of rapprobement, both sides have not abandoned the old hatbits and the "hegemennic" reunification policy. Both Korcan states are self-righteuus and justifying on the utufication issue (i.e., failing to display empathy and modicum of genuine reconciliarion that are so essential to any successful negotiation and meaningful dialogue between the two former adversaries).

In the post-Cold War and post-Kim II Sung era, North and South Korea must learn to live in peace and harmony as neighbors. Yet, they continue to practice "hegemony" rathet than "cocxistence" even if the solemn pledge is made and the signature is affixed on the document of the basic agrecment to bristg about reconciliation and peace in their mutual relations. The question of "hegemony" or "coexistence," in short, has not been setrled as of yet between the rwo rival states and antagonistic regimes on the Korean peninsula.

Under those circumstances, the future prognosis and prospects do not look promising. In 1993, North Korea announced the succalled, "Ten-Point Prockamation" on the "greater national unity of Korean unification," which has now become a sacred creed in the pust-Kim Il Sung era.? In 1998, North Korea reaffirmed this policy wher Kim Jong Il presensed his new Five Poine Guidelines on Greater National Unity on April $18^{\text {(i1 }} .2$ ? South Korca's successive governments continue to harbor the desire of inducing internal

\footnotetext{
"For an analysis ot the three-point principle, and related issues of unfication policics sec Young Whan

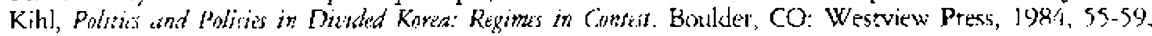
205-30

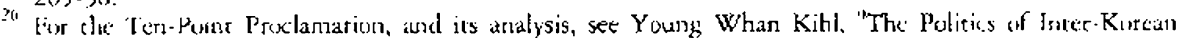
Relations: Cisexistence or. Reurification?" In Young Whan Kihl, Korta and she Wimld: Bey:sad tbe Cald War. Boulder, Col: Westriew Press, 1994, pp. 133-52, 118.49.

These art: (1) upholding the priniple of national independence, (2) seckirtg unity based on partiotism, (3) improvity North-South tclacions, (f-1) opposition to foreign domination ind anti-unification forcts, and (5) stepping up mational contars, dialogue, solidarity. and anicy.
} 
change in North Korea. In 1998, the ROK government of President Kim Dae Jung has adopted a new initiative toward North Korea called the "Sunshine" policy in the attempt to engage the North in inter-Korean dialogue and cooperation. Yet, the Seoul government has typically pursued the strategy of engaging North Korea in inter-Korean dialogue and exchanges, in the hope that the radical change and reform, similar to what transpired in the formet socialist camp of East Lurope and the Soviet Union, inight repeat itself in the post-Kin Il Sung North Korea. Transformation of thetoric to action, however, still seems to be far off.

The problem of Korea's future and reunification, under those circumstances, is most likely to be settled by political means, instead of relying exclusively on the non-political methods. The promotion of inter-Korean cooperation in the international arena exemplifies the functional approach to Korean problem-solving. The political settlement of the Korean question could be arranged primiarily berween the two Korean states, and secondarily berwen the two Koreas and among the external powers surrounding Korea that actively maintain interests in Korea.

\section{CONCLUSION}

The question of "how" and "why" certain types of mulcilateral organizations succeed in yromoting inter-Korean cooperation, while other types either fail or end up with mixed results, can be answered by examining the factors of (a) domescic interests, (b) international pressures, and $(c)$ che context of intcraction between the two Korean states. Understanding domestic political econony, for instance, requires not only the examination of donestic intcrests within each Korea, but also needs to take into consideration the nature of interaction between domestic politics and international institutions, as acell as the changing structure of world politics and economy

The best case to illustrate the above points is the rematkable history of long-drawn bartles on the LN membership, which was played our by Seoul and Pyongyang during the Cold War years. However, with the Cold War's sudden ending, the ROK and the DPRK changed their respective hardened positions almose overnight and applied for simultaneous membership) in the United Nations in May 1991. despite the continuous display of mut ual animosity and rivalry. Dumestic political interests and the ncw international mvirument hive combined to exert strong pressures on each Korea to reassess its respective and time-honored stance on the question of UV membership, either as a single or separate entry into the world organization. This interplay of domestic and international interests seemed to underlie and propel, in varying degrees, the dynamics of linkage between multilateral organizations and promotion of inter-Korcan relations.

Fistally, to give a comparative assessment on the impact of threc cases of the UNDP, the CPU, and the KEDO on the DPRK's diplomacy, it can be stated rhat each of these IC Os represents a prototype of the multilateral organizations exerting varied influences upon promoting inter-Korean relations. North Korea's receptivity to some multilatural organizations, like the LNDP, is a positive sign of the socialist hermit-kingdom getting 
ready to overcome the state of self-imposed isolation and to join the international community. As for the second category of certain $\mathrm{LN}$ specialized agency experiments with the DPRK, like the LPU and the ITU, the results of the record are not positive in terms of these organizations enhancing incer-Korean cooperation. Other UN specialized agencies, like the ICAO, the FAO, and the WHO, have been given greater receptivity by the DPRK, the agencies that have produced a limited but positive impact on ince-Korean cooperation. The overtiding criterion for the DPRK's decision on whether to participate in the $1 G O$ activities is the interest consideration given by the grovernment.

This is also the case with on-going experiments and with the third type of multilateral organizations, most conspicuourly the KEDO and certain other NGOs, which are primarily engaged with the humanitarian and food assistance program. These international bodies have been given limited acess to the local personnel as well as to the necdy population. What this entails in the long run, in terms of positive or negative impacts on the DPRK's diplomacy, is unclear and difficult to say. Yet, if the KEDO's task is fully completed at the end, it will exert potentially siznificant payoffs not only to the DPRK ieself, but also to the other incerested parties concerned about Korta's future. In this sense, the on-going expcriments of the DPRK linkage with all types of mutrilateral organizations mist $L x$ viewed as encouraging from the standpoint of assuring peace and security on the Korean peninsula via insticution-building in mulcilateral diplomary.

Because of the faiture of certain IGOs, like the UPU, the ITU, and perhaps the IAEA, to promote inter-Korean exchanges and cooperation, the NGOs have lately come to fill in the gap. The outstanding examples are International Red Cross (IRC) and U.S.-based PVOs (Private Voluntary Organizations). The latter boxdy is planning to send 1,000 tors of seed potatoes to North Korea in 1994.28 About thirty NGOs are said to have sent food and emergency aid to North Korca. Actually, sixty representatives of some torry NGOs have met in Beijing in May 1999 to discuss large-scale assistance to the DPRK ${ }^{20}$ "Necessity is the morher of invention," as the popular saying goes, and it is so trut in the case of the DPRK opening it to some multilateral organizarions. The ROK benefited from it indirectly, at least, as a spillover effect across the DMZ. The Rajin-Sonbong FTEZ, which received che initial boost from the LNDP in its inception, and the Hyundai-DPRK joint versture of Mt. Kumgang tourism, launched in Novenber 1998, are two examples of new institutional experiments that require furcher scruciny.

Whather North Korea's opening to selected ICOs, like the UNDP, the WEP, the $\mathrm{FAO}$, and indirectly to the JMF and the World Bank, will amount to anything substantive and enduring is not clear and difficult to say at the moment. This remains to be seen in the future. During 1998, some 120 DPRK officials are said to have received overscas' training on such subject-matters as economics, management, and international law, according to Seoul's newspraper quoting a high-ranking KOK official ${ }^{30}$ In a way, these multilateral organizations are now filling the gap that the two Korcas left behind because of their

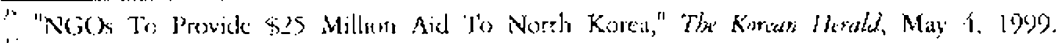

$\therefore$ Ibid.

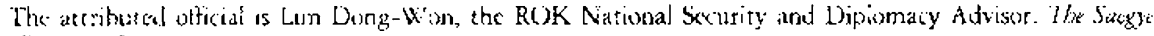
Whi, Mirch 1. [996]
} 
inabilicy to coxprerate face-to-face. At any rate. we are reminded rhat "it is conventional wisdom now that interdependence has implications for power as well as for wealeh," and that international institutions have come to constitute a valuable set of instruments for promoting the interests of states through cooperation. 31 Fnhancing "inter-Korean cooperation via multilateral organizations," however flawcd and inadequate it may look, makes eminent good common sense in the post-Cold War era and, therefore, it must Le encouraged and put to practical use.

\section{REFERENCES}

Cotson, Jancs. 1998. "The Rajin-Sonbong Free Trade Zone Experiment: North Korea in Pursuic of New International Linkages." In Nonth Knean finteirn Relations in the Post-Cold War Exa, ad. Sambel C. Kim. Naw York and Hong Kung: Oxford University Press. ad. 1995. Politicj and Policy in the Nat Karan State: Fom Rab Tae-Wom to Kim Yaing-Sam. New York: St. Martin's Press.

Hahn, Bue Ho and Chae Jin Lee. eds. 1999. Patherns of Inter-Kortan Relations. Seoul: The Sejong lostitute.

Katzenstein, Petcr J., Rohert O. Keohane, and Stephen D. Krasner. 1998. "International Organization and the Study of World Policics." Sntemationat Orgentoating 52(4) (Autumn):

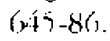

Keohinse, Robert O. 1998. "Intenacional Inscitutions: Can Interdependence Work?" Fortign Polin: (Spring): 82-96.

and Joseph Nyc, Jr. 1985. "Two Cheers for Multilateralism." Fowrign Polizy: (Fall).

Kild, Young Whan. 1988. "The Muse that Reared: North Korea's Nuclear Deat-Making with the Unired States." Paiffe Fores 13(2) (Fall): 5.26.

1998. "North Korea and the United Nations." In North Karean Foreign Relanms

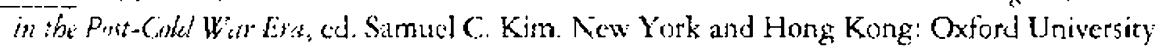
Pincss.

1095. "Democratization and Foreign Policy." In Politis and Police in the Nere Konten Stati: Fwn Rib Tate-Wo to Kim Young-Sam, ed. James Cotton. New York: St. Marcin's Press.

(993. "Kukje Kikuwa Nambukhan Kyoryu Hyupryuk: Muinjejomkwa Jonmang" ["Intergational Organization and Soutz-North Korean Cooperation: Problems and

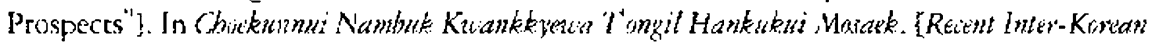
Rtalitins and Searby for [inffed Korea] Seoul: Korea Liniversity Asiatic Rescarch Center: $243-46$.

Kih, Young Whan and Peter Hayes, eds. 1997. Peate and Secumb in Northeant Aria: The

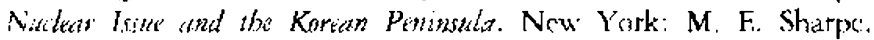

Kim, Sumued C. 1997. "North Korea and the Lited Nations." Int:rnational Jumal of Kentean Simder l(1) (Spring): ? ? -110 .

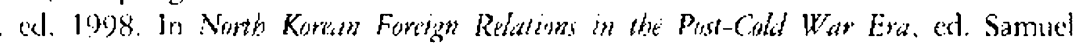
C. Kin. Vew York and Hong Kong: Oxford Lniversity Press.

Koh. B. C. 19ys. "Nurth Korea's Policy Toward the United Nations." Korka Jourmal 35(1) (Spring).

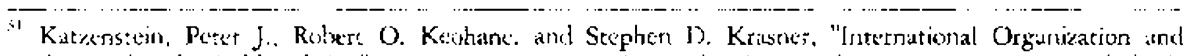

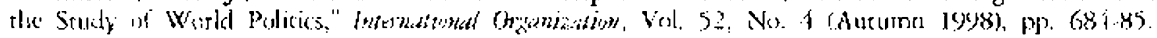


lee, Sco.Hang. 1992. "Kukje Kiku Ch'amyorll I'bugnan Nam-buk. Sinrae Kikujeunginbarian

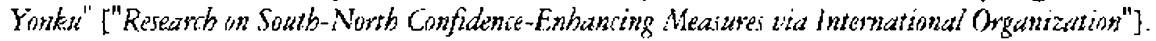
Seoul: ROK Foreign Ministry Institute of Diplomacy and National Security, Policy Studies Series 91-20: $15-18$.

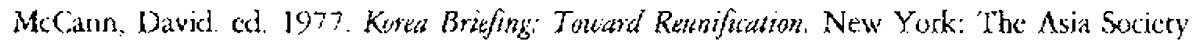
and $M$. E. Sharpe

Mitrany, David. [1943] 1966. A Working Peate Systent. Funciunal Development of Enternational Organization. London: Royal Institute of International Affairs. Chicago: Quadriangle Puklishers.

Oterdorfer, Don. 1997. The Tiu Koteas: A Contemporary Histony. Reading, Mass.: Addison-Wesley. Segal: Leon V. 1998. Disarming Strangers: Nuclear Diplomacy with North Korea. Princeton: Princeton University Press.

Soutb-Nortb Dialogut in Kored. Various Issues. Senul: Office of the South-North Dialogue. Suh, 1)at Sook and Chae Jin I.ee. eds. 1997. North Kirea After Kim II Sung. Boulder, Colo.: Lynne Rienner Publishers.

ROK National Unification Board. 1988. A White Haper on South-Nonh Dialongu in Korea. Secoll: National Unification Buard.

Yerabomk of Intematimat Organization 1998-99. Brussels. Linion of International Association. 1.998. 